\title{
Proceedings of the Conference on 75 years of Nuclear Fission: Present Status and Future Perspective (Fission75)
}

Bhabha Atomic Research Centre,

Mumbai 400 085, India

8-10 May 2014

\section{Editors}

D C BISWAS

K MAHATA

V M DATAR

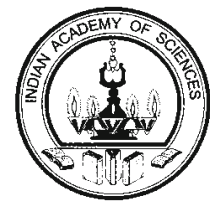

Published by

Indian Academy of Sciences

Bangalore 